\title{
NEW METHOD EVALUATION OF DETAIL MATERIAL AND HEAT FLOWS FOR SINGLE STRING CEMENT CLINKER PLANT
}

\author{
Prihadi Setyo Darmanto $^{a, *}$, I Made Astina ${ }^{a}$, \\ Alfian Kusuma Wardhana $^{a}$, Alfi Amalia ${ }^{b}$, Arief Syahlan ${ }^{b}$ \\ ${ }^{a}$ Institut Teknologi Bandung, Faculty of Mechanical and Aerospace Engineering, Jalan Ganesha 10, 40132 \\ Bandung Indonesia \\ ${ }^{b}$ Indonesia Cement and Concrete Institute, Jalan Ciangsana Raya, 16968 Bogor, Indonesia \\ * corresponding author: prihadisetyo@gmail.com
}

\begin{abstract}
Material flow in each main equipment of a cement clinker plant, which is very useful for controlling the process, is impossible to be measured during operation due to very high temperatures. This paper intends to overcome the difficulties associated with the measurement of these material flow values. This study presents a new method of calculating material flow (gas and solid) in each main equipment of a single string conventional suspension preheater type of a cement clinker plant. Using the proposed method, mass flow rate at a clinker cooler, kiln, suspension preheater (SP) and even each cyclone separator can be calculated with a heat conservation error less than $1 \%$. With the application of the least square method for solving the overdetermined system of mass and heat conservation equations obtained in the cyclones of SP, the flow of gas and solid materials entering and exiting each cyclone that cannot be measured directly in the operating plant can be approached. Based on the operation temperature data of gas and solid flows monitored in the control room of an Indonesian cement plant as a case study, the mass flow rate of gas and solid entering and exiting as well as separation efficiency of each cyclone can be calculated. The results show that the separation efficiencies of cyclones 1, 2, 3 and 4 are $95 \%, 91.89 \%, 84.09 \%$ and $79.51 \%$ respectively. Finally, this study will be very useful by providing data that are impossible to gather by a direct measurement in an operating plant, due to a very high process temperature constraint, for operational control needs, new equipment design, process simulation using computational fluid dynamics (CFD) software and even modification of existing equipment. The proposed method can be applied to all types of modern cement clinker plant configurations, either with or without a calciner including the double strings.
\end{abstract}

KEYWORDS: Mass \& heat conservations, suspension preheater, cyclone, separation efficiency.

\section{INTRODUCTION}

Due to the fact that processes in a cement manufacturing plant are highly exothermic, it is necessary to conduct a precise heat consumption analysis in an effort to optimize heat conservation and efficiency [1]. Understanding the actual heat consumption and its conservation efforts have been main issues in cement industries [2]. Therefore, a heat audit at a cement plant is conducted to identify opportunities for decreasing heat consumption, increasing the productivity and improving the production has been carried out 3 . The heat consumption assessment of Portland cement production in a Thailand's cement plant was also reported and found 3.29 GJ per ton of cement [4. Based on the audit results, there are several methods to improve heat conservation in cement plants: improving the quality of kiln feed in the kiln, modifying the preheater cyclone, repairing the control system, utilizing waste heat and improving the combustion process at the kiln [5]. The realization of the utilization of waste heat discharged into the environment through the preheater and cooler to $5.26 \mathrm{MW}$ of electrical heat in a cement plant in Ethiopia has been reported [6]. Previous studies using heat and exergy analyses in kilns [7, preheater and calciner [8], as well as a thermodynamic analysis of processes in a raw mill [9] and a heat transfer analysis of preheater hot gas [10] found that there are many opportunities left out unexplored for heat conservation. One of the notable efforts in heat conservation is by using renewable materials as an alternative of using fossil fuel, such as: industrial waste [11, biomass (e.g. rice husk and bamboo) [12, 13] and tyres [14. No less important is the use of alternative materials as a clinker substitution to reduce the production cost and maintain their environment sustainability (e.g. steelmaking slag [15], fly ash [16], pozzolanic material [17], limestone and micro-silica [18]).

Modifying processes and equipment was done in an effort to increase the heat efficiency. A top cyclone preheater modification was conducted to increase its separation efficiency and to reduce the return dust, which can contaminate the fine coal in the coal mill was explored in [19, 20. A modification of the process using co-fuel combustion and modelling of calcination process in the calciner was explored in 21, 22. A modification 
of the tertiary duct of kiln hood and modernization of the kiln using pyroclone calciner was explored in [23, 24]. A development of the design concept as well as the evolution of the main burner was explored in [25]. These studies used computational fluid dynamics (CFD) to understand the mechanism of any equipment modification. CFD simulations required precise and accurate data such as mass flowrate of the gas and material entering into the equipment [26, 27], but it was rarely mentioned where the data came from. As simulation results, heat consumption, life cycle inventory, and waste generated from the cement manufacturing plant can be carried out profoundly [28, 29]. However, obtaining the precise input data from a currently active cement manufacturing plan remain as prevailing issue. The issues are due to limited measurement instruments and methods and very high temperature conditions, which sometimes make the measurements impossible to do if the factory is running.

The input data measurement for the simulations can be obtained from a direct possible measurement in a cement plant. These data consist of operational parameters: feed rate, clinker production, fuel mass rate, air consumption rate for transporting fuel, clinker cooling air rate and equipment surface temperature. Meanwhile, the material mass conservation between two interconnected devices cannot be measured directly when the plant is in operation. The examples are between the cyclones in the suspension preheater (SP) during the preheating process of materials; between the cyclone and the calciner during a calcination process; and the between kiln entrance and the clinker cooler. These mass conservation calculations such as the input and output of a material flow rate in each cyclone stage and calciner are necessary for the design and modification of a cyclone and calciner. The difficulties in achieving direct measurements in the cement manufacturing equipment are still critical due to technical limitations such as high temperature, dusty environment and others [30]. Furthermore, the separation efficiency of each cyclone is closely related to the mass flow rate and heat in the whole SP. For example, to obtain cyclone separation efficiency values, the design results are normally used in the calculation of mass and heat conservations [31]. However, this certainly does not match the conditions of the real equipment when the factory is running. Thus, parametrization based on a real operating condition value is necessary to obtain a realistic approach for the preheater system design modification. A single string preheater is currently still used in a cement manufacturing plant. This technology consumes high thermal heat while having low production capacity. In order to increase the efficiency of the fuel used and increase the production, a plant modification using a newly designed calciner shall be conducted [32]. Thus, the aim of this research is to propose a new method for estimating the value of cyclone efficiency by utilizing detail mass and heat conservation equations on each cyclone in the preheater system, without making direct mass flow rate measurements on the related equipment. To simplify the results of modelling and calculation, the equation of mass and heat conservations at cyclone preheaters are formed as a matrix and solved using the least squares method. The equation of this study is an overdetermined equation system that could be solved by using an approximation method. From the estimated cyclone separation efficiency value, the mass flow rate in each component of the cyclone can be approximated.

The literature survey indicates that studies of detail materials and heat flow evaluation of the cyclone separator in the SP are limited in number and scope. Generally, only limited to kiln [33]35], clinker cooler [36] and all the main equipment of a cement plant as a whole [37. The additional objective of this study is to contribute providing detailed data required for an equipment design, modification, control of plant operation, and detail heat audit.

\section{MATERIALS AND METHOD}

\subsection{MATERIALS}

The SP configuration of cement plants depends on the plant manufacturers. According to the classification proposed by Schmidt 38, the configuration of the studied dry process cement plant suspension preheater is a conventional suspension preheater (SP) type as shown in Fig. 1] while a schematic diagram of the whole cement plant main equipment is presented in Fig. 2. SP consists of four cyclone separators and its riser duct is installed in series.

Fig. 1 shows raw-meal being inserted into SP through the riser duct of the top cyclone, while the material coming out of the preheater is transported towards the kiln for further processing to become clinker.

The fuel used is coal, and is introduced into the kiln using the main burner. Table 1 shows the chemical composition of kiln feed and coal that are normally used in an Indonesian cement plant, including in this study.

\subsection{MASS AND heAT CONSERVATION EQUATIONS}

From Fig. 2, with the assumption that the plant condition is steady and the chemical composition of the kiln feed and fuel (coal) is as presented in Table 1 and the ash contained in fuel forms clinker, the material flow conservation of the plant can be written as Eq. 1. The production of the clinker $m_{c l i}$ can be evaluated by Eqs. (2) to (8).

$$
m_{k f}+m_{\text {coal }}+m_{t r-a i r}+m_{\text {coal-air }}=m_{c l i}+m_{H_{2} O-k f}+m_{u s n e p \_k f \_1}+m_{g a s-k f}
$$




\begin{tabular}{cccc}
\hline Kiln feed composition & \% of mass & Coal composition & \% of mass \\
\hline $\mathrm{CaO}$ & 43.29 & $\mathrm{H}_{2}$ & 4.44 \\
$\mathrm{MgO}$ & 1.43 & $\mathrm{C}$ & 73.40 \\
$\mathrm{SiO}_{2}$ & 13.82 & $\mathrm{~N}_{2}$ & 1.30 \\
$\mathrm{Al}_{2} \mathrm{O}_{3}$ & 3.37 & $\mathrm{O}_{2}$ & 11.10 \\
$\mathrm{Fe}_{2} \mathrm{O}_{3}$ & 1.77 & $\mathrm{~S}$ & 0.50 \\
$\mathrm{H}_{2} \mathrm{O}$ & 0.32 & $\mathrm{H}_{2} \mathrm{O}$ & 4.70 \\
$\mathrm{LOI}\left(\mathrm{CO}_{2}, \mathrm{Na}_{2} \mathrm{O}, \mathrm{K}_{2} \mathrm{O} \& \mathrm{SO}_{3}\right)$ & 36.00 & Ash + dust & 13.00 \\
\hline
\end{tabular}

TABLE 1. Chemical composition of kiln-feed and coal.

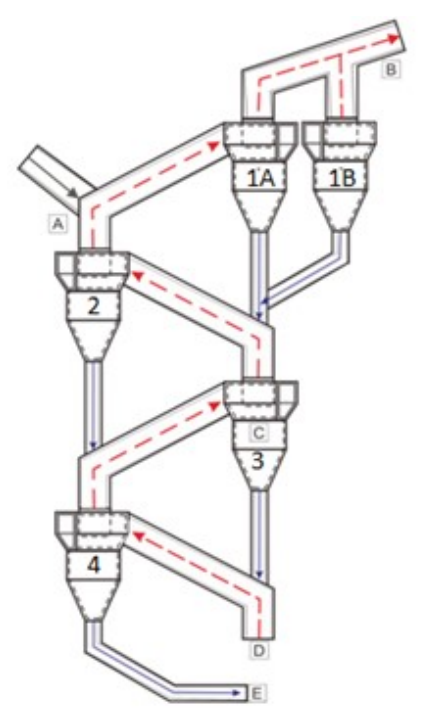

Notation:

$\longrightarrow$ Materials flow

$\ldots$ Gas and dust flow

A. Entering kiln feed to SP

B. Hot gas and unseparated dust

C. Crclone separator

D. Hot gas and clinker dust

E. Separated kiln feed to kiln

Figure 1. Suspension preheater (SP).

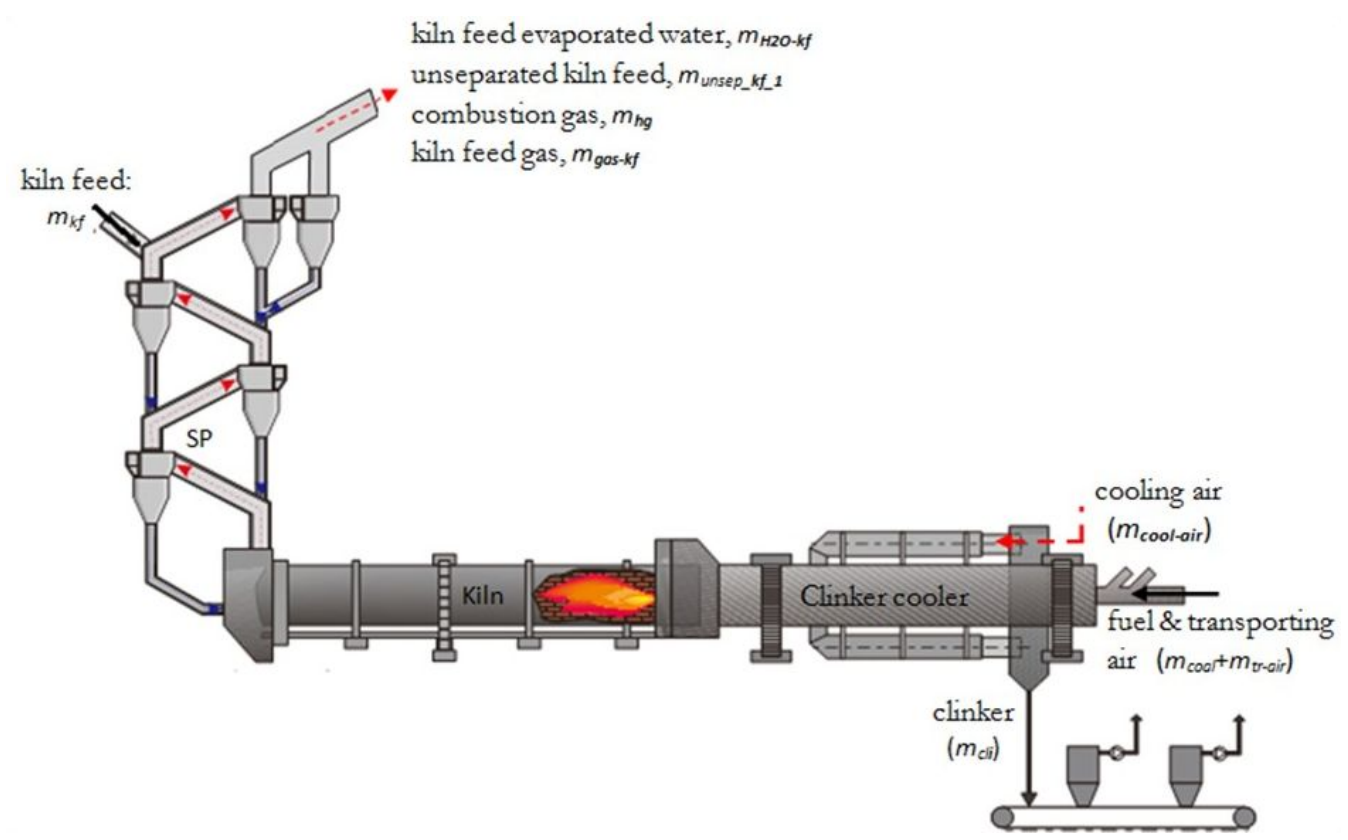

Figure 2. Material flow in cement clinker's plant main equipment. 


$$
\begin{gathered}
m_{c l i}=m_{s e p-k f c}+m_{a s h} \\
m_{s e p-k f c}=\left(1-L O I_{k f}\right) \cdot m_{s e p-k f} \\
m_{g a s-k f}=\left(L O I_{k f}-H_{2} O_{k f}\right) \cdot m_{s e p-k f} \\
m_{s e p-k f}=\eta_{C 1 . A \& 1 . B} \cdot m_{k f} \\
m_{\text {unsep_kf_1 }}=\left(1-\eta_{C 1 . A \& 1 . B}\right) \cdot m_{k f} \\
m_{a s h}=a s h_{c o a l} \cdot m_{c o a l} \\
m_{H_{2} O-k f}=H_{2} O_{k f} \cdot m_{s e p-k f}
\end{gathered}
$$

If it is assumed as complete combustion, the mass flow rate of the hot gas $\left(m_{h g}\right)$ is equal to the flue gas resulted from coal combustion process. The value of $m_{h g}$ can be estimated by Eq. (9):

$$
m_{h g}=\left(1-a s h_{c o a l}\right) \cdot m_{c o a l}+m_{t r-a i r}+m_{c o a l-a i r}
$$

Based on the Fig. 2, the heat conservation equation of the plant can be written in Eq. (10):

$$
\sum E n_{i n}=\sum E n_{o u t}
$$

where $\sum E n_{\text {in }}$ is the sum of the heat flow entering the plant equipment, while $\sum E n_{\text {out }}$ is the sum of the heat flow exiting the plant. The heat flow or heat entering the plant consists of:

(1.) Heat flow of kiln feed entering the SP (Eq. 11):

$$
E n_{k f}=m_{k f} \cdot h_{k f}\left(T_{k f}\right)
$$

(2.) Heat flow of coal entering the kiln (Eq. 12):

$$
E n_{\text {coal }}=m_{\text {coal }} \cdot h_{\text {coal }}\left(T_{\text {coal }}\right)
$$

(3.) Heat flow of air entering the plant through clinker cooler and main burner (Eq. 13):

$$
E n_{\text {air }}=\left(m_{t r-a i r}+m_{\text {cool-air }}\right) \cdot h_{\text {air }}\left(T_{\text {air }}\right)
$$

(4.) Heat flow resulted by coal combustion process (Eq.14):

$$
E n_{\text {coal-comb }}=m_{\text {coal }} \cdot N H V_{\text {coal }}
$$

Meanwhile, the flow of heat exiting plant's main equipment, with the assumption that the temperature of dust and gas exiting from $\mathrm{SP}$ is equal $T_{h g 1}$, contains of:

(1.) Heat flow of clinker product at temperature $T_{c l i}($ Eq. 15):

$$
E n_{c l i}=m_{c l i} \cdot h_{c l i}\left(T_{c l i}\right)
$$

(2.) Heat flow of coal combustion process gas exiting from the top of the cyclone of SP (Eq. 16):

$$
E n_{h g}=m_{h g} \cdot h_{h g}\left(T_{h g 1}\right)
$$

(3.) Heat flow of vapour created by the evaporation of water content in kiln feed exits from SP (Eq. 17):

$$
E n_{\text {vapor }-k f}=m_{H_{2} O-k f} \cdot h_{\text {vapor }}\left(T_{h g 1}\right)
$$

It is noted that the mass of vapour created by the coal combustion process is included in the mass flow of flue gas.

(4.) Heat flow of unseparated kiln feed exiting from the top of the cyclone of SP (Eq. 18):

$$
\text { En } n_{\text {unsep-kf-1 }}=m_{\text {unsep-kf-1 }} \cdot h_{k f}\left(T_{h g 1}\right)
$$

(5.) Heat flow of kiln feed gas resulting from the calcination process, mostly $\mathrm{CO}_{2}$, exits from SP (Eq. 19):

$$
E n_{g a s-k f}=m_{g a s-k f} \cdot h_{C O_{2}}\left(T_{h g 1}\right)
$$




\begin{tabular}{lccc}
\hline Material & $\mathrm{A}$ & $\mathrm{B}$ & $\mathrm{C}$ \\
\hline Raw meal & 0.206 & 101 & -37 \\
Clinker & 0.186 & 54 & 0 \\
Coal & 0.262 & 390 & 0 \\
$\mathrm{Air}$ & 0.237 & 23 & 0 \\
$\mathrm{CO}_{2}$ & 0.196 & 118 & -43 \\
$\mathrm{O}_{2}$ & 0.218 & 30 & 0 \\
Vapor $\left(\mathrm{H}_{2} \mathrm{O}\right)$ & 0.443 & 39 & 28 \\
\hline
\end{tabular}

TABle 2. Values of $A, B$, and $C$ of Eq. 24, 41].

(6.) Heat of the clinker formation where the value can be calculated by Bogue's equation multiplied by the rate of the clinker production [39] (Eq. 20):

$$
\begin{aligned}
E n_{f o r m}=m_{c l i}\left\{7.646\left(\mathrm{CaCO}_{3}\right)_{k f}+6.48\left(\mathrm{MgCO}_{3}\right)_{k f}+4.11\left(\mathrm{Al}_{2} \mathrm{O}_{3}\right)_{k f}-\right. & \\
- & \left.-5.176\left(\mathrm{SiO}_{2}\right)_{k f}-0.59\left(\mathrm{Fe}_{2} \mathrm{O}_{3}\right)_{k f}\right\}
\end{aligned}
$$

where $\left(\mathrm{CaCO}_{3}\right)_{k f},\left(\mathrm{MgCO}_{3}\right)_{k f},\left(\mathrm{Al}_{2} \mathrm{O}_{3}\right)_{k f},\left(\mathrm{SiO}_{2}\right)_{k f}$, and $\left(\mathrm{Fe}_{2} \mathrm{O}_{3}\right)_{k f}$ are mass based percentage of each substance contained in the kiln feed. It should be noted that for each $\mathrm{kg}$ of clinker produced, the heat of the clinker formation consists of calcination heat $\left(E n_{\text {calc }}\right)$, which is endothermic and the heat of clinkerization or sintering $\left(E n_{\text {clink }}\right)$, which is exothermic.

Hence, the heat of the clinker formation is the difference between the calcination and the sintering heat. Calcination is the decomposition reaction of $\mathrm{CaCO}_{3}$ to form $\mathrm{CaO}$ and $\mathrm{CO}_{2}$ while sintering is the reaction process of the formation of oxides contained in the clinker. Sintering occurs in the temperature range of 1250 to $1450{ }^{\circ} \mathrm{C}$, thus it only occurs in the kiln. The heat of this calcination reaction which can occur in the $\mathrm{SP}$ and kiln is considered constant at $425 \mathrm{kcal} / \mathrm{kg}$ of $\mathrm{CaCO}_{3}$ 40. By determining the calcination heat per $\mathrm{kg}$ of $\mathrm{CaCO}_{3}$, the calcination heat per $\mathrm{kg}$ of clinker produced can be calculated. Finally, we can summarize the calculation in Eq. (21).

$$
E n_{\text {clink }}=E n_{\text {calc }}-E n_{\text {form }}
$$

(7.) Evaporation heat of the water content in the kiln feed and coal exits from SP (Eq. 22):

$$
E n_{\text {evap }}=\left(m_{\mathrm{H}_{2} \mathrm{O}-\mathrm{kf}}+m_{\mathrm{H}_{2} \mathrm{O}-\mathrm{coal}}\right) h_{f g}
$$

where $h_{f g}$ is the enthalpy of the water evaporation process.

(8.) Heat loss by radiation and convection $\left(Q_{l o s s}\right)$ through the overall surface area of the main equipment $A_{t o t}$ that can be calculated by the proposed formula [41] (Eq. 23):

$$
Q_{\text {loss }}=A_{\text {tot }}\left(4 \cdot 10^{-8}\left(T_{\text {surf }}^{4}-T_{a m b}^{4}\right)+80.33\left(\frac{T_{\text {surf }}-T_{a m b}}{2}\right)^{-0.724}\left(T_{\text {surf }}-T_{a m b}\right)^{1.333}\right)
$$

Enthalpy of the substances can be calculated, if their temperatures are known from a measurement, using Eq. (24)

$$
h(T)=\int_{T_{1}}^{T_{2}} C_{p} d T=A+B T^{2} \cdot 10^{-6}+C T^{3} \cdot 10^{-9}
$$

where $C_{p}$ is the specific heat of the substance and $T_{1}$ is the reference temperature. The value of constants $A$, $B$, and $C$ for limited substances and gas are shown in Table 2 .

\subsection{Methodology}

In general, a cement plant is equipped with measuring devices and instrumentations to monitor operating parameters such as temperatures and draft pressures. A weighing feeder is applied for measuring the mass flow rate of the kiln feed and coal. An oxygen content monitoring system is put in the kiln and SP gas outlets. An obstruction meters for measuring the air flow are generally available at the control system of the plant. In addition, the flow of dust returning from the unseparated kiln feed leaving for the SP is also measured. This allows an estimation of the separation efficiency of the top cyclone by using Equation (6). The first methodology of the study is the evaluation of mass conservation of the whole plant based on the measurement results of these instrumentation devices using Equations (1) to (9). The second methodology is to solve the mass and heat rates in each main equipment in more detail, (e.g. clinker cooler, kiln, SP and each cyclone separator). Additional 


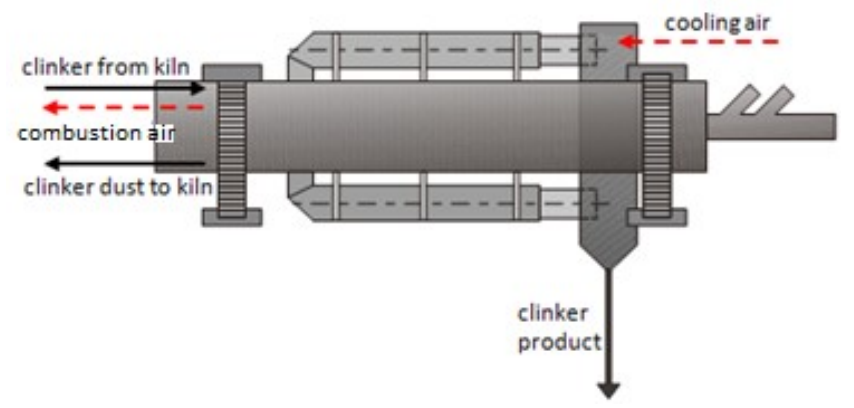

Figure 3. Materials flow in planetary cooler.

mass and heat conservation equations are required for each equipment. These equations are interdependent and can be formed into linear algebraic equations and solved simultaneously. However, especially for cyclones, because the number of equations is greater than the number of parameters to be searched for, the approximation solution taken is by using the least square method with the minimum square of a residual error as the criteria.

\subsection{MASS AND HEAT CONSERVATION EQUATIONS OF PLANETARY CLINKER COOLER}

For the planetary clinker cooler, a schematic diagram of mass flow entering and leaving the planetary cooler is presented in Fig. 3. The mass conservation equation can be written as Eq. (25):

$$
m_{c l i \_k}+m_{c o o l-a i r}=m_{c l i}+m_{c l i d \_t o \_k}+m_{c o o l \_a i r \_k}
$$

where $m_{c l i}, m_{c l i \_k}, m_{c o o l-a i r}, m_{c o o l \_a i r \_k}$ and $m_{c l i d \_t o \_k}$ are the mass flow rates of the clinker product, clinker entering the cooler, cooling air entering the cooler, cooling air entering the kiln (combustion air) and clinker dust returning to kiln, respectively. With the assumption that there is no leakage in this cooler, the mass flow rate of the cooling air is equal to the combustion air minus the transporting air.

The rate of the clinker mass from leaving the kiln and entering the cooler must be equal to the sum of the clinker production and the returning clinker dust back to the kiln. This clinker dust is carried by the combustion air back from the cooler to the kiln. The percentage of clinker dust returning to the clinker production will be assumed in the calculation of the mass conservation in the cooler. The heat conservation calculation error in the cooler and kiln is not more than $1 \%$. With limits determined like this and with the measurement data from the plant, the calculation of the mass and heat conservations in the cooler can be carried out. The planetary cooler heat conservation equation is written in Eq. 26]:

$$
E n_{c l i \_k}+E n_{c o o l-a i r}=E n_{c l i}+E n_{c l i d \_t o \_k}+E n_{c o o l \_a i r \_k}+Q_{l o s s}
$$

The flow of heat entering the planetary cooler consists of:

(1.) Heat flow of clinker from kiln at a temperature $T_{c l i \_k}$ :

$$
E n_{c l i \_k}=m_{c l i \_k} \cdot h_{c l i}\left(T_{c l i \_k}\right)
$$

(2.) Heat of cooling air:

$$
E n_{\text {cool_air }}=m_{\text {cool_air }} \cdot h_{a i r}\left(T_{a i r}\right)
$$

Meanwhile, the flow of heat leaving for the cooler, assuming that the temperature of the dust returning to kiln and the gas exiting from the cooler is equal to $T_{h g \_c}$ consists of:

(1.) Heat flow of clinker product $E n_{c l i}$ at a temperature $T_{c l i}$ as mentioned in Eq. (15).

(2.) Heat of combustion air entering the kiln $E n_{s e c \_a i r \_c}$ at temperture $T_{h g \_c}$ is:

$$
E n_{s e c \_a i r \_c}=m_{c o o l \_a i r \_k} \cdot h_{h g \_c}\left(T_{h g \_c}\right)
$$

(3.) Heat flow of clinker dust returning to kiln $E n_{c l i d \_k}$ at temperture $T_{h g \_c}$ :

$$
E n_{c l i d \_k}=m_{c l i d \_t o \_k} \cdot h_{c l i}\left(T_{h g \_c}\right)
$$

Heat loss by radiation and convection $Q_{\text {loss_c }}$ through the surface area of the clinker cooler $\left(A_{\text {cooler }}\right)$ can be calculated by Eq. (23). In Eqs. (25) and (26), the value of the mass rate of the clinker dust returning to the kiln $\left(m_{\text {clid_to_k }}\right)$ and combustion air temperature cannot be measured directly at the plant. However, the mass and heat conservation in the kiln can be evaluated with the minimum acquisition limit between the heat entering and exiting the kiln. Using this condition, the Eqs. 27) to (30) can be solved by completing the heat conservation of the cooler. 


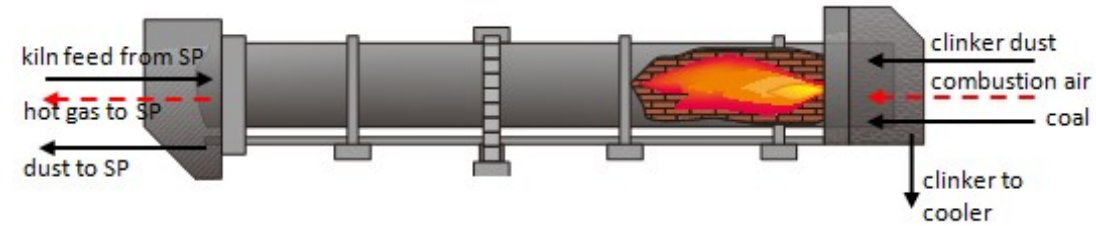

Figure 4. Materials flow in the kiln.

\subsection{MASS AND heAt CONSERVATION EQUATIONS OF THE KILN}

For kiln system, the mass flow in and from the kiln is described in Fig. 4 The equation of mass conservation is written in Eq. (31):

$$
m_{\text {sep-kf-4}}+m_{c l i d \_t o \_k}+m_{\text {coal }}+m_{\text {comb_air }}=m_{c l i \_k}+m_{c l i d \_t o \_s P}+m_{h g \_t o \_s P}
$$

where

$m_{\text {sep }-k f-4}=$ mass flow rate of kiln feed from SP.

$m_{\text {coal }}=$ mass flow rate of coal.

$m_{\text {comb air }}=$ mass flow rate of combustion air (cooling air mcool-air and transporting air mtr-air).

$m_{\text {clid_to_SP }}=$ mass flow of clinker dust entering the SP.

$m_{h g \_t o \_s P}=$ mass flow rate hot gas entering the SP.

The hot gas entering the SP consists of flue gas, as mentioned in Eq. (9), and $\mathrm{CO}_{2}$, including other gasses from the calcination and burning process. The portion of the calcinated kiln feed can be evaluated using equation (4) multiplied by the percentage of the kiln feed calcinated in the kiln (\%Calc_k). Thus, the value of $m_{h g \_t o \_s P}$ can be described as Eq. (32),

$$
m_{h g \_t o \_s P}=m_{h g}+\left(\% C a l c \_k \cdot m_{g a s \_k f}\right)
$$

The other notations were already mentioned in the mass conservation of the cooler. While the heat conservation equation of the kiln is as follows (Eq. 33p,

$$
\begin{aligned}
E n_{k f \_t o \_k}+E n_{c o a l}+E n_{c o a l-c o m b}+E n_{s e c \_a i r \_c}+E n_{t r \_a i r} & +E n_{c l i d \_k}=E n_{c l i \_k}+E n_{c l i d \_t o \_S P}+ \\
& +E n_{f o r m \_k}+E n_{h g \_t o \_s P}+Q_{l o s s \_k}
\end{aligned}
$$

The flow of heat entering the kiln consists of:

(1.) Heat flow of kiln feed from the SP at a temperature $T_{i n \_k}$ (Eq. 34):

$$
E n_{k f \_t o \_k}=m_{s e p-k f-4} \cdot h_{k f}\left(T_{i n \_k}\right)
$$

(2.) Heat of coal entering the kiln as defined in Equation 12.

(3.) Heat from coal combustion process (Eq. 14).

(4.) Heat flow of cooling and transporting air (Eq. 13).

(5.) Heat of clinker dust returning from cooler as written in Eq. (30).

While the heat flows leaving for the kiln consist of:

(1.) Heat flow of clinker product $E n_{c l i \_k}$ to the cooler (Eq. 27).

(2.) Heat flow of clinker dust returning to the SP En $n_{c l i d \_t o \_S P}$ in which its temperature is assumed equal to the temperature of the hot gas leaving for kiln $T_{i n \quad k}$ :

$$
E n_{c l i d \_t o \_S P}=m_{c l i d \_t o \_s P} \cdot h_{c l i}\left(T_{i n \_k}\right)
$$

(3.) Net heat of calcination and clinkerization process in the kiln $E n_{f o r m \_k}$ that can be assumed equal to the sum of calcination heat and clinkerization heat. Hence, the value of $\bar{E} n_{\text {form } \_k}$ can be written as follows, Eq. (36).

$$
E n_{f o r m \_k}=E n_{\text {calc_k }}+E n_{\text {clink }}
$$

where $E n_{\text {calc_k }}=\%$ Calc_k$\cdot E n_{\text {calc }}$. Here, $\%$ Calc_k $k$ can be estimated indirectly when the evaluation of the heat conservation in the kiln is carried out. The value of $\%$ Calc $k$ also depends on the percentage of the kiln feed that was calcined in the SP $(\%$ Calc_SP $)$. Therefore, $\%$ Calc_k $k=1-\%$ Calc_SP. In this study, we assume that the calcination process in the SP occurs at the cyclone $3\left(\% C a l c \_S P \_C 3\right)$ and the lowest cyclone $\left(\% C a l c \_S P \_C 4\right)$ and their riser ducts. Thus $\% C a l c \_S P=\%$ Calc_SP_C $3+\% C a l c \_S P \_C 4$. 
(4.) The temperature of the heat flow of hot gas from the kiln to the SP is $T_{i n \_k}$. The total mass of this hot gas is the sum of the mass flow rate of the combustion gas $m_{h g}$ (Eq. 9 and $\mathrm{CO}_{2}$ produced by the calcination process of the kiln feed in the kiln equal to $\left(\%\right.$ Calc_k $\left.k m_{\text {gas }-k f}\right)$. Therefore, the heat flow of the hot gas can be calculated as follows (Eq. 37),

$$
E n_{h g \_t o \_s P}=m_{h g} \cdot h_{h g}\left(T_{i n_{k}}\right)+\left(\% \text { Calc_k} \cdot m_{g a s-k f}\right) \cdot h_{C O 2}\left(T_{i n_{k}}\right)
$$

The heat loss by radiation and convection $Q_{l o s s \_k}$, and the heat loss through the surface area of the kiln $\left(A_{k i l n}\right)$ can be calculated by Equation (23).

\subsection{Detail mass and heat conservation equations of SP System and Each Cyclone SEPARATOR}

The flow of solid materials and gas of the SP is presented in Fig. 1 and its related mass conservation equation can be written as follows (Equation 38,

$$
m_{k f}+m_{c l i d \_t o \_S P}+m_{h g \_t o \_S P}=m_{s e p-k f-4}+m_{H_{2} O-k f}+m_{u n s e p \_k f \_1}+m_{h g}+m_{g a s-k f}
$$

It should be noted that the values of $m_{k f \_t o \_k}$ and $m_{c l i d \_t o \_s P}$ are known by solving the kiln mass conservation equation.

Heat flow into the SP consists of:

(1.) Heat of kiln feed entering the SP, $E n_{k f}$.

(2.) Heat of clinker dust returning from the kiln, $E n_{\text {clid_to_sP }}$, which is represented by Eq. (35).

(3.) Heat flow of hot gas from kiln, which was presented by Eq. (37) and consisted of the sum of the heat flow rate of the combustion gas $m_{h g}$ and LOI produced by the calcination process of the kiln feed.

While the heat flows leaving the SP consist of:

(1.) Heat flow of unseparated kiln feed by top cyclones (Eq. 18.

(2.) Heat flow of coal combustion hot gas exiting from the top cyclone as formulated by Eq. (16).

(3.) Heat of evaporated water content in the kiln feed as written by Eq. (17).

(4.) Heat of the gas product of the kiln feed calcination and burning process, mainly $\mathrm{CO}_{2}$. Its value is approximated by Eq. (19).

(5.) Heat flow of the kiln feed entering the kiln at a temperature $T_{i n_{k}}$ as presented in Equation (34).

(6.) Heat of the clinker formation in SP En form_SP that can be assumed equal to the heat of the clinker formation $E n_{f o r m}$ (Eq. 20 minus the heat formation absorbed in the kiln $E n_{f o r m \_k}$ :

$$
E n_{f o r m \_S P}=E n_{f o r m}-E n_{f o r m \_k}
$$

It should be noted that the heat formation in the SP only consists of the calcination heat. Its value can be estimated based on the percentage of the calcined kiln feed in the cyclones 3 and 4 . We can write this term as $E n_{f o r m \_S P}=\left(\% C a l c \_S P \_C 3+\% C a l c \_S P \_C 4\right) \cdot E n_{\text {calc }}$.

(7.) Heat loss by radiation and convection $Q_{\text {loss_SP }}$ through the SP's surface area $\left(A_{S P}\right)$ that can be calculated by Eq. 23.

Finally, the heat conservation equation for the SP is written in Eq. 40,:

$$
\begin{aligned}
E n_{k f}+E n_{c l i d \_t o \_s P}+E n_{h g \_t o \_s P}=E n_{u n s e p-k f-1}+E n_{c l i d \_t o \_s P}+E n_{k f \_t o \_k}+ & \\
& +E n_{f o r m \_S P}+E n_{g a s-k f}+E n_{v a p o r-k f}+Q_{l o s s \_S P}
\end{aligned}
$$

For understanding the flows of mass and heat at each cyclone separator that is very useful for the plant operation and design as well as equipment modification, its formulation will be derived one by one. The design of top cyclone $1 \mathrm{~A}$ and $1 \mathrm{~B}$ consist of 2 cyclones of a diameter smaller than their lower cyclones. The reason of this design is to achieve a higher separation efficiency. The schematics of these top cyclones are presented in Fig. 5 , while the lower cyclones are depicted in Fig. 5 b.

For the top cyclones, assuming no flow leakage, the incoming mass flow consists of:

(1.) kiln feed, $m_{k f}$ at temperature $T_{k f}$.

(2.) flow of unseparated kiln feed from the cyclone $2, m_{u n s e p \_k f \_2}$ where its temperature is $T_{h g 2}$.

(3.) gas flow from the cyclone below at a temperature $T_{h g 2}$, which consists of combustion gas $\left(m_{h g}\right) i n$ and kiln feed gas $\left(\mathrm{CO}_{2}\right.$ and others $),\left(m_{\text {gas }-k f}\right)$ in . 


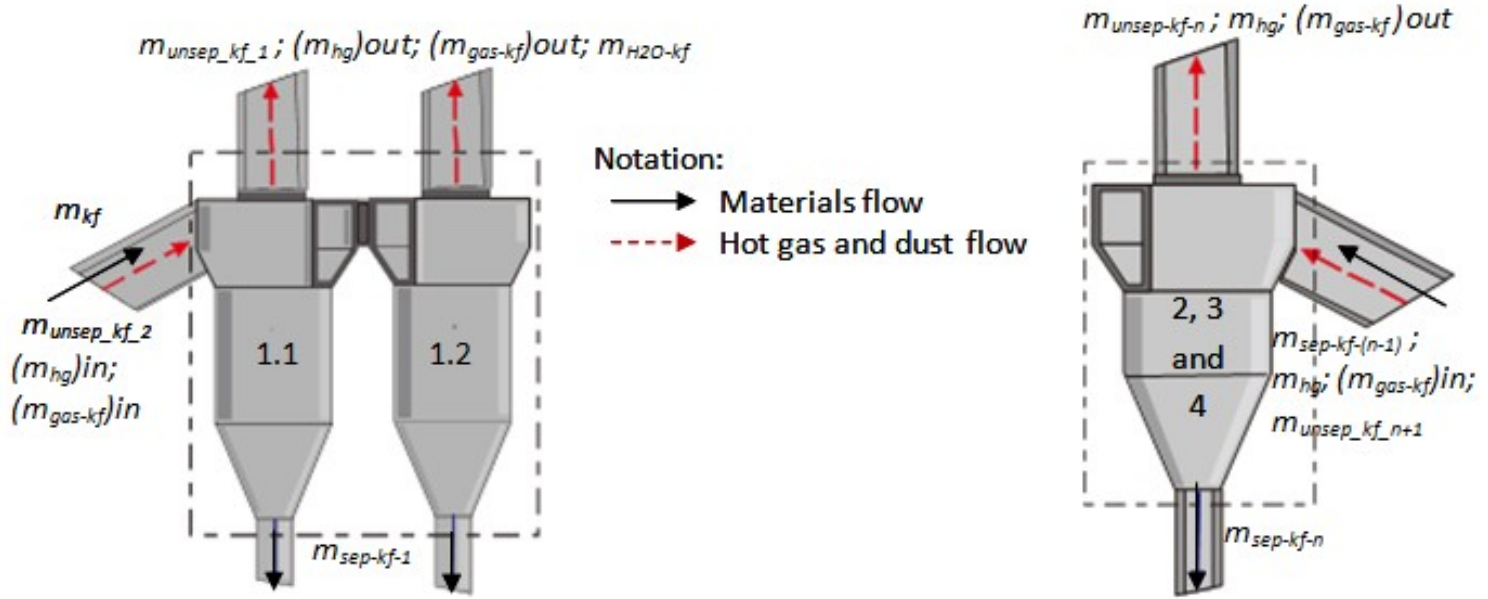

Figure 5. Mass flow of top (left) and other (right) cyclones.

While the outflow of mass consists of:

(1.) separated kiln feed to the cyclone $2, m_{s e p-k f-1}$.

(2.) unseparated kiln feed at a temperature $T_{k f 1},\left(m_{u n s e p \_k f \_1}\right)$.

(3.) combustion gas, kiln feed gas and water vapour $\left(m_{H_{2} O-k f}\right)$ at temperature $T_{k f 1}$.

The mass conservation equation for the top cyclone can be written as Eq. (41).

$$
\begin{aligned}
m_{k f}+m_{\text {unsep_kf_2 }}+\left(m_{h g}\right) i n+\left(m_{\text {gas }-k f}\right) i n=m_{\text {sep-kf-1 }}+m_{H_{2} O-k f} & +m_{\text {unsep_kf_1 }}+ \\
& +\left(m_{h g}\right) \text { out }+\left(m_{\text {gas }-k f}\right) \text { out }
\end{aligned}
$$

For a general SP operation, the gas temperature that heats the kiln feed is slightly higher than the kiln feed temperature when exiting the cyclone $\left(T_{k f 1}\right)$. These temperatures are measured and can be read from the control room. The rate of the kiln feed and unseparated dust filtered by baghouse can also be measured. Assuming that the dust from cyclone 2 will be filtered back by the top cyclone. Thus, the material that has been filtered by the top cyclone is a part of the circulating material in the the SP. Furthermore, the ratio of $\left(m_{k f}-m_{\text {unsep_kf_1 }}\right)$ and $m_{k f}$ can be used for the calculation of the value of its separation efficiency, $\eta_{C 1 . A \& 1 . B}$. In this case, $\left(m_{g a s-k f}\right) i n=\left(m_{g a s-k f}\right)$ out $=m_{g a s-k f}$ and $\left(m_{h g}\right) i n=\left(m_{h g}\right)$ out $=m_{h g}$ and it will be valid for the following derived equations. Based on this operating conditions, the top cyclone separation efficiency can be calculated by Eq. (5) and its heat conservation can be written as follows (Eq. 42,

$$
\begin{aligned}
E n_{k f}+m_{{\text {unsep } f_{2}}} \cdot h_{k f}\left(T_{h g 2}\right)+m_{h g} \cdot h_{h g}\left(T_{h g 2}\right)+m_{g a s-k f} \cdot h_{C O_{2}}\left(T_{h g 2}\right)=E n_{h g}+E n_{g a s-k f}+ \\
+E n_{\text {vapor-kf }}+E n_{\text {unsep }-k f-1}+m_{\text {sep-kf-1 }-1} \cdot h_{k f}\left(T_{k f 1}\right)+Q_{\text {loss_C1 }}
\end{aligned}
$$

where $Q_{\text {loss_C1 }}$ is the heat loss by radiation and convection through the top cyclone surface area $\left(A_{C 1}\right)$ that can be calculated by Eq. (23). Using the same notation of materials and gas flows as denoted in Fig. 5right, the mass conservation equation of the cyclone 2 can be written as Eq. (43).

$$
\begin{aligned}
& m_{s e p-k f-1}+m_{u n s e p \_k f \_3}+\left(m_{h g}\right) i n+\left(m_{g a s-k f}\right) i n=m_{s e p-k f-2}+m_{u n s e p \_k f \_2}+ \\
& +\left(m_{h g}\right) \text { out }+\left(m_{\text {gas }-k f}\right) \text { out }
\end{aligned}
$$

While its heat conservation equation is (Eq. 44):

$$
\begin{aligned}
& m_{s e p-k f-1} \cdot h_{k f}\left(T_{k f 1}\right)+m_{u n s e p \_k f \_3} \cdot h_{k f}\left(T_{h g 3}\right)+m_{h g} \cdot h_{h g}\left(T_{h g 3}\right)+m_{g a s-k f} \cdot h_{C O_{2}}\left(T_{h g 3}\right)= \\
& =m_{\text {sep-kf-2}} \cdot h_{k f}\left(T_{k f 2}\right)+m_{\text {unsep_kf_2 }} \cdot h_{k f}\left(T_{h g 2}\right)+m_{h g} \cdot h_{h g}\left(T_{h g 2}\right)+m_{g a s-k f} \cdot h_{C O_{2}}\left(T_{h g 2}\right)+ \\
& +Q_{\text {loss_C2 }}
\end{aligned}
$$

For the cyclone 3 , the temperature of the exiting gas and solid materials are $T_{h g 3}$ and $T_{k f 3}$, respectively. Meanwhile, the temperature of the gas entering this cyclone from the lowest cyclone is $T_{h g}$. The calcination reaction starts at a temperature of around $600^{\circ} \mathrm{C}\left[42,44\right.$ and the kiln feed temperature from cyclone $3\left(T_{k f 3}\right)$ is 
higher than $600^{\circ} \mathrm{C}$. Hence, a part of the kiln feed is calcined. By assuming that the percentage of calcined kiln feed in cyclone 3 is \%Calc_SP_C3, then the $\mathrm{CO}_{2}$ formed from this reaction and the associated reaction heat must be taken into account in the mass and heat conservation equation. Hence, the mass conservation equation for cyclone 3 can be written as follows (Eq. 45,

$$
\begin{array}{r}
m_{\text {sep-kf-2 }}+m_{\text {unsep_kf_4 }}+\left(m_{h g}\right) i n+\left(m_{\text {gas }-k f}\right) \text { in }=m_{\text {sep-kf-3 }}+m_{\text {unsep_kf_3 }}+ \\
+\left(m_{h g}\right) \text { out }+\left(m_{\text {gas }-k f}\right) \text { out }
\end{array}
$$

where

$$
\begin{array}{r}
\left(m_{\text {gas }-k f}\right) \text { out }-\left(m_{g a s-k f}\right) \text { in }=\% C a l c \_S P \_C 3 \cdot m_{g a s-k f}=\left(m_{s e p-k f-2}+m_{u n s e p \_k f \_4}\right)- \\
-\left(m_{s e p-k f-3}+m_{u n s e p \_k f \_3}\right)
\end{array}
$$

and its heat conservation equation is:

$$
\begin{aligned}
& m_{\text {sep-kf-2}} \cdot h_{k f}\left(T_{k f 2}\right)+m_{\text {unsep_kf_4 }} \cdot h_{k f}\left(T_{h g 4}\right)+m_{h g} m_{h g} \cdot h_{h g}\left(T_{h g 4}\right)+ \\
& +m_{g a s-k f} \cdot h_{C O 2}\left(T_{h g 4}\right)=m_{s e p-k f-3} \cdot h_{k f}\left(T_{k f 3}\right)+m_{\text {unsep_kf_3 }} \cdot h_{k f}\left(T_{h g 3}\right)+ \\
& \quad+E n_{f o r m \_S P \_C 3}+m_{h g} \cdot h_{h g}\left(T_{h g 3}\right)+m_{g a s-k f} \cdot h_{C O_{2}}\left(T_{h g 3}\right)+Q_{\text {loss_C3 }}
\end{aligned}
$$

It should be noted that the kiln feed calcination process in cyclone $3\left(m_{s e p-k f c-3}\right)$ continues in the lowest cyclone due to the higher temperature of the hot gas coming from the kiln. Therefore, a part of the kiln feed mass transforms to $\mathrm{CO}_{2}$ in this lowest cyclone. The mass conservation equation of the lowest cyclone is finally written as (Eq. 48,

$$
\begin{aligned}
& m_{\text {sep-kf-3}}+\left(m_{h g}\right) i n+m_{c l i d \_t o \_s P}+\left(\% \text { Calc_k } \cdot m_{g a s-k f}\right)= \\
& =m_{s e p-k f-4}+m_{u n s e p \_k f \_4}+\left(m_{h g}\right) \text { out }+\left(m_{g a s-k f}\right) \text { out }
\end{aligned}
$$

The gas produced by the calcination process in the lowest cyclone is equal to (Eq. 49),

$$
\begin{aligned}
\left(m_{\text {gas }-k f}\right) \text { out }-\left(\% C a l c \_k m_{\text {gas }-k f}\right)= & \% \text { Calc_SP_C4m } m_{\text {gas }-k f}= \\
& =\left(m_{s e p-k f-3}+m_{c l i d \_t o \_S P}\right)-\left(m_{s e p-k f-4}+m_{\text {unsep_kf_4 }}\right)
\end{aligned}
$$

The related heat conservation equation can be given as Equation (50),

$$
\begin{aligned}
m_{s e p-k f-3} \cdot h_{k f} & \left(T_{k f 3}\right)+E n_{c l i d \_t o \_s P}+E n_{h g \_t o \_S P}=m_{u n s e p \_k f \_4} \cdot h_{k f}\left(T_{h g 4}\right)+ \\
& +m_{h g} \cdot h_{h g}\left(T_{h g 4}\right)+m_{g a s-k f} \cdot h_{C O_{2}}\left(T_{h g 4}\right)+E n_{k f \_t o \_k}+E n_{f o r m \_S P \_C 4}+Q_{l o s s \_C 4}
\end{aligned}
$$

The mass and heat flows in cyclones 2, 3 and 4 (lowest cyclone) cannot be calculated sequentially. This is due to the unknown value of the mass of the kiln feed separated by cyclones 2 and 3 and unseparated kiln feed from cyclones 3 and 4 . These four unknown parameters are interdependent and must be solved simultaneously. To evaluate all four parameters simultaneously, equations $(43)$ to $(45),(47),(48)$ and $(50)$ are used and written in the form of a matrix (Eq. 51):

$$
[A] \times[X]=[B]
$$

The matrices $[A],[X]$ and $[B]$ are represented by Equations (51), (52) and (53), respectively. Matrix $[A] 6 \times 4$ is a multiplier constant of unknown variables, while the matrix $[B] 6 \times 1$ is a constant resulting from the known constant value of the equation (51).

$$
\begin{gathered}
{[A]=\left[\begin{array}{cccc}
1 & 0 & -1 & 0 \\
h_{k f}\left(T_{k f 2}\right) & 0 & -h_{k f}\left(T_{h g 3}\right) & 0 \\
-1 & 1 & 1 & -1 \\
-h_{k f}\left(T_{k f 2}\right) & h_{k f}\left(T_{k f 3}\right) & h_{k f}\left(T_{h g 3}\right) & -h_{k f}\left(T_{h g 4}\right) \\
0 & -1 & 0 & 1 \\
0 & -h_{k f}\left(T_{k f 3}\right) & 0 & h_{k f}\left(T_{h g 4}\right)
\end{array}\right]} \\
{[X]=\left[\begin{array}{c}
m_{\text {sep-kf-2 }} \\
m_{\text {sep-kf-3 }} \\
m_{\text {unsep_kf_3 }} \\
m_{\text {unsep_kf_4 }}
\end{array}\right]}
\end{gathered}
$$




$$
[B]=\left[\begin{array}{c}
m_{s e p-k f-1}-m_{u n s e p \_k f \_2} \\
m_{s e p-k f-1} \cdot h_{k f}\left(T_{k f 1}\right)+ \\
m_{h g} \cdot\left\{h_{h g}\left(T_{h g 3}\right)-h_{h g}\left(T_{h g 2}\right)\right\}+ \\
m_{g a s-k f} \cdot\left\{h_{C O_{2}}\left(T_{h g 3}\right)-h_{C O_{2}}\left(T_{h g 2}\right)\right\}- \\
m_{\text {unsep }-k f-2} \cdot h_{k f}\left(T_{h g 2}\right)-Q_{l o s s \_C 2} \\
0 \\
m_{h g} \cdot\left\{h_{h g}\left(T_{h g 4}\right)-h_{h g}\left(T_{h g 3}\right)\right\}+ \\
m_{g a s-k f} \cdot\left\{h_{C O}\left(T_{h g 4}\right)-h_{C O}\left(T_{h g 3}\right)\right\}- \\
E n_{f o r m \_S P \_C 3}-Q_{l o s s \_C 3} \\
m_{c l i d \_t o \_S P}-m_{s e p-k f-4}- \\
\left\{\left(1-\% C a l c_{k}\right) \cdot m_{g a s-k f}\right\} \\
E n_{c l i d \_t o \_S P}+E n_{h g \_t o \_s P}-m_{h g} \cdot h_{h g}\left(T_{h g 4}\right)- \\
m_{g a s-k f} \cdot h_{C O}\left(T_{h g 4}\right)-E n_{k f \_t o \_k}- \\
E n_{f o r m \_S P \_C 4}-Q_{l o s s \_C 4}
\end{array}\right]
$$

Matrix $[X] 6 \times 1$ is the variable which shall be solved. From the equation (51), it is known that the number of unknown variables is less than the number of equations (overdetermined equations). A system that has a number of equations greater than the number of variables usually do not have a solution or cannot be solved directly [45. The conservation of mass and heat equations in the form of matrix as written in Eqs. (52) to (54) are stand-alone equations so that the rank matrices $[A]$ and $[A \mid B]$ cannot be reduced from one another because the matrix compiler equation is not a combination of other equations. Thus, the overdetermined equation systems usually have inconsistent variables. However, the solution can still be found using the Least Squares method, which is to find the value to fulfil the equation of results with the minimum square of the residual error [46. The method used is by least squaring the matrix $[A]$ by multiplying the transpose matrix itself $[A]^{T}$ so that the matrix $[A]^{T}[A]$ has the same number of rows and columns. The matrix $[A]^{T}[B]$ will change the row of the matrix $[B]$ so the matrix $[B]$ has the same line as the number of rows of $[A]^{T}$ as shown in Eq. (55).

The variable values in the matrix $[X]$ can be found by multiplying the inverse matrix $\left[A^{T} A\right]^{-1}$ on both sides of the equation as described in Eq. (56), that can be solved using mathematical software.

$$
\begin{aligned}
{[A]^{T}[A] \times[X] } & =[A]^{T}[B] \\
{\left[A^{T} A\right]^{-1}\left[A^{T} A\right] \times[X] } & =\left[A^{T} A\right]^{-1}[A]^{T}[B]
\end{aligned}
$$

From equation (56), the values of $X \approx H_{L S}$ are called as unique least squares approximate solution that comply the Least Square method, and are defined by Eq. (57).

$$
X_{L S}=\left[A^{T} A\right]^{-1}\left[A^{T} B\right]
$$

Knowing the approximating values of $X$, the approximate value of the separation efficiency of the cyclones 2,3 , and 4 can be calculated using the following Eqs. (58)- 60] [47, 48].

$$
\begin{aligned}
& \eta_{C 2}=\frac{m_{s e p-k f-2}}{m_{\text {sep-kf-1 }}+m_{\text {unsep_kf_3 }}} \\
& \eta_{C 3}=\frac{m_{s e p-k f-3}}{m_{\text {sep-kf-2 }}+m_{\text {unsep_kf_4 }}-\left(\% \text { Calc_SP_C3 } m_{\text {gas }-k f}\right)} \\
& \eta_{C 4}=\frac{m_{s e p-k f-4}}{m_{s e p-k f-3}+m_{c l i d \_t o \_s P}-\left(\% C a l c \_S P \_C 4 \cdot m_{g a s-k f}\right)}
\end{aligned}
$$

The approximate value of the cyclone separation efficiency can be substituted into the mass conservation equation of each cyclone to recalculate the value of $X$ that meets the mass conservation law. The final results of $X$ can be used to evaluate the flow of heat in each cyclone with a minimum error. Hence, it can be accepted from an engineering point of view (i.e. error $<1 \%$ ). The flowchart of the calculation steps is shown in Figure6. All above mentioned equations and methods of calculations have been adopted as base in developing the substantial engineering equation solver (i.e., in the form of executable programs) and used to calculate detail materials and heat flows and conservations. 


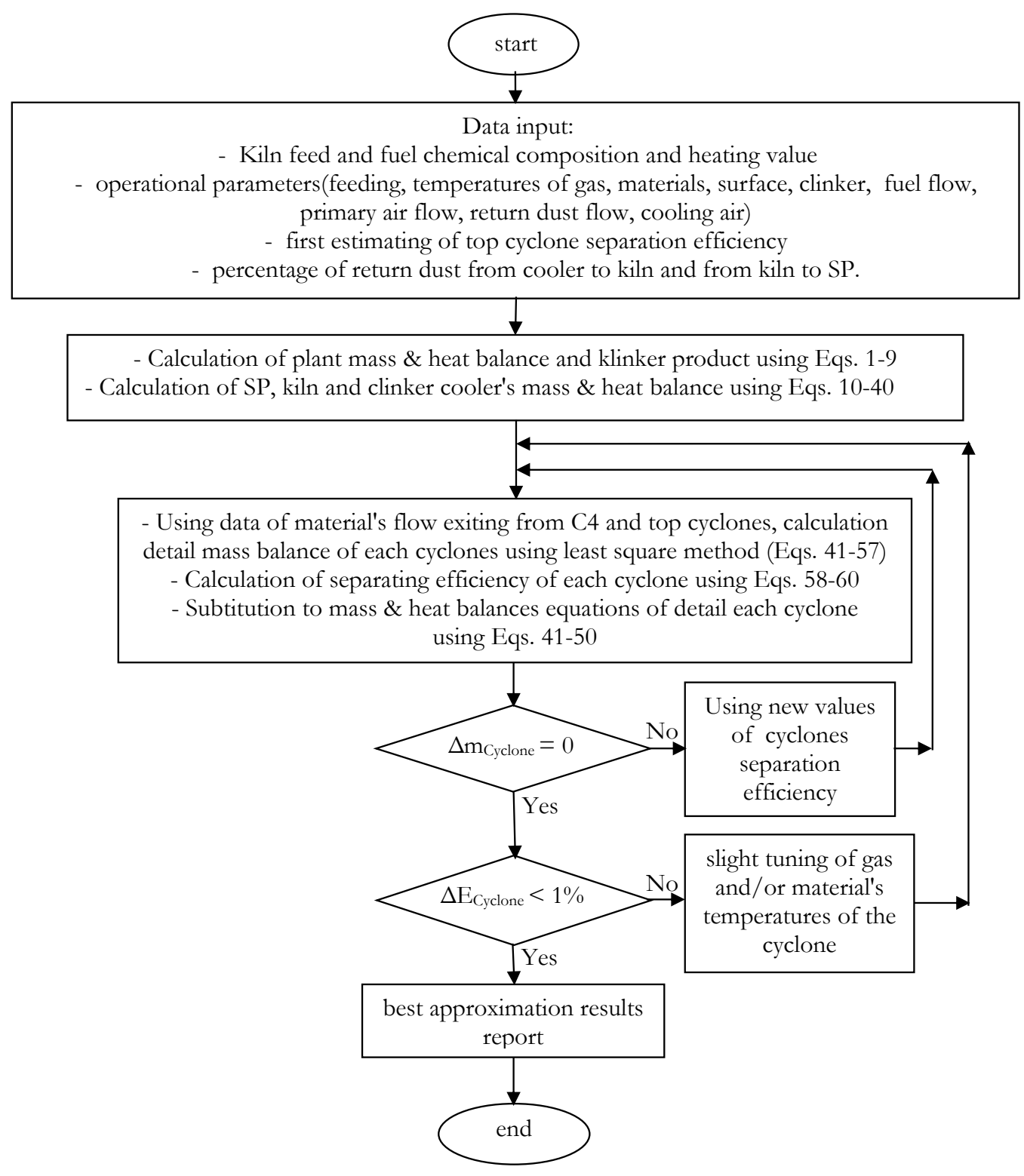

Figure 6. Flowchart of the calculation steps.

\section{RESUlts AND DISCUSSION}

\subsection{Operational Data parameters}

A cement factory plant in Indonesia, Tonasa 2, was used as the object of this study. Daily average data at a normal operation capacity were used for the current analysis. These data were taken from the control room and direct field measurement. The data for input values are classified into several groups (i.e. kiln feed, coal, SP, kiln, and cooler data). The coal consumption is 271 tons per day (TPD) or $3.137 \mathrm{~kg} / \mathrm{s}$ with $6,100 \mathrm{kcal} / \mathrm{kg}$ of coal nett heating value. The rate of the transporting air is $2.08 \mathrm{~m}^{3} / \mathrm{s}$. The rate of the inlet kiln feed is 3,195 TPD. The rate of the return dust is $158.8 \mathrm{TPD}(1.85 \mathrm{~kg} / \mathrm{s})$. The remaining oxygen percentage in the kiln and top cyclone outlets are $2.5 \%$ and $2.7 \%$, respectively, and can be used to estimate the kiln excess air and SP false air [41. The ambient temperature is $33^{\circ} \mathrm{C}$. Based on these measurement data, the production of clinker, flue gas and kiln feed gas can be evaluated using Eqs. (2) to (9). Meanwhile, the data for kiln, planetary cooler, and $\mathrm{SP}$ are based on measurement results and general assumptions of normal cement plant operations and are given in Tables 3 and 4. Another parameter that can't be measured directly in the plant is the mass flow rate of the re-circulated dust from the cooler to the kiln and from the kiln to the SP, in this study, their values are assumed as $15 \%$ and $17 \%$ of the clinker production rate, respectively. 


\begin{tabular}{lccc}
\hline Parameters & Unit & Kiln & Cooler \\
\hline Average surface temperature & $\left({ }^{\circ} \mathrm{C}\right)$ & 330.7 & 189.2 \\
Cylinder diameter & $(\mathrm{m})$ & 4.5 & 2.3 \\
Length of cylinder & $(\mathrm{m})$ & 75 & 16 \\
Number of cylinder & unit & 1 & 11 \\
Clinker product temperature & $\left({ }^{\circ} \mathrm{C}\right)$ & - & 190 \\
Entering air temperature & $\left({ }^{\circ} \mathrm{C}\right)$ & - & 33 \\
Estimated return dust from cooler & $(\%)$ & 15 & - \\
\hline
\end{tabular}

TABLE 3. Input data for kiln and planetary cooler.

\begin{tabular}{lccccc}
\hline Parameters & Unit & Cyclone 1 & Cyclone 2 & Cyclone 3 & Cyclone 4 \\
\hline Average surface temperature & $\left({ }^{\circ} \mathrm{C}\right)$ & 164.1 & 194.2 & 198.8 & 226 \\
Total surface area & $\left(\mathrm{m}^{2}\right)$ & 450.7 & 376.9 & 376.5 & 455.3 \\
Hot gas inlet temperature & $\left({ }^{\circ} \mathrm{C}\right)$ & 560 & 694 & 867 & 1190 \\
Hot gas exit temperature & $\left({ }^{\circ} \mathrm{C}\right)$ & 360 & 560 & 694 & 867 \\
Separated kiln feed temperature & $\left({ }^{\circ} \mathrm{C}\right)$ & 345 & 545 & 680 & 837 \\
Estimated return dust from kiln & $(\%)$ & - & - & - & 17 \\
Estimated kiln feed calcinated exit SP & $(\%)$ & - & - & - & 25 \\
\hline
\end{tabular}

TABLE 4. Input data for each cyclone of the SP.

\subsection{Plant mass and heat CONSERVATions}

Using the available input data, the mass and heat conservations for the case study plant can be evaluated using Eqs. (10) to 23). The results of the mass and heat conservations calculation is presented in the form of per unit mass of clinker products (i.e., per kg of clinker produced). With the kiln feed mass fed to the plant of 3,195 TPD and the measured top cyclone separation efficiency of around $95 \%$, the clinker production is approximately $1,978 \mathrm{TPD}(22.9 \mathrm{~kg} / \mathrm{s})$. For the whole clinker plant, the overall mass and heat conservations per unit mass of clinker produced are given in Table 5 Generally, the heat consumption at a higher capacity of the cement plant is lower. From the results, it can clearly be seen that the formation of heat per $\mathrm{kg}$ of clinker is around $425 \mathrm{kcal}$. The heat of this clinker formation generally consists of the calcination heat of $\mathrm{CaCO}_{3}$, and clinkerization heat to form clinker-contained oxides. The calcination process is endothermic, while the clinkerization process is an exothermic process. Because both processes occur at a high temperature range $\left(600{ }^{\circ} \mathrm{C}-1,450{ }^{\circ} \mathrm{C}\right)$, an additional heat is needed to maintain the temperature of the kiln and Suspension Preheater (SP). This is the reason why the plant heat consumption is far above its clinker formation heat. This excess heat is finally carried away by the flue gas, $\mathrm{CO}_{2}$ and other gasses out of the SP. This hot gas, with a low oxygen content, is used as a heat source for a drying of coal and raw materials. In modern cement factories, the flue gas is even used as for electricity generation. In addition, the excess heat is also carried out by clinker products. The clinker heat is recovered in the cooler to increase the combustion air temperature and reduce the coal requirements. In effort to reduce the production cost and supporting environmental sustainability, part of the fuel used is low rank coal and alternative fuels. However, by shifting to lower rank coal with a high water content and alternative fuels, the specific heat consumption could increase to $\pm 850 \mathrm{kcal} / \mathrm{kg}$ of the produced clinker [49].

\subsection{CoOler AND KILN MASS AND heAT CONSERVATiOnS}

The calculation results of the mass and heat conservation at the cooler and kiln, using Eqs. (24) to (36), are given in Tables 6 and 7 respectively. The absolute value of the incoming and outgoing difference heat of the cooler is less than $1 \%$. The temperature of the combustion air entering the kiln is around $960{ }^{\circ} \mathrm{C}$ and its recovery heat efficiency is $74.55 \%$. This combustion air temperature is in the range of the value measured by Alfi et.al [49]. Meanwhile, the percentage of the heat recovery in the cooler is relatively high when compared to the grate cooler, which is widely used in large capacity factories. This is caused by the conditions on the planetary cooler with the entirety of the cooling air being used as a combustion air. Whereas, on the grate cooler, not all of the cooling air is used as combustion air.

The consequence is that the clinker temperature coming out of the cooler is generally higher on the planetary cooler than in the case of the grate cooler. The heat loss from the cooler is large enough that it can be further utilized (i.e., for drying coal in Tonasa 2 plant [50]). In Table 7, the mass and heat conservation per kg of clinker produced in the kiln can be seen. The difference between the rate of heat entering and exiting the kiln is insignificant, with an approximate value of $0.46 \%$. This value is obtained by assuming that $17 \%$ of clinker from 


\begin{tabular}{lcccc}
\hline \multirow{2}{*}{ Parameters } & \multicolumn{2}{c}{ Inlet } & \multicolumn{2}{c}{ Outlet } \\
& mass $(\mathrm{kg})$ & heat (kcal) & mass (kg) & heat(kcal) \\
\hline Kiln feed in & 1.6155 & 20.541 & - & - \\
Coal to main burner & 0.1370 & 837.102 & - & - \\
Total combustion air & 1.5850 & 11.442 & - & - \\
Clinker production & - & - & 1.0000 & 37.289 \\
Combustion gas including excess air & - & - & 1.7042 & 154.620 \\
Kiln feed gas & - & - & 0.5528 & 46.744 \\
Return dust & - & - & 0.0805 & 6.887 \\
Clinker heat formation & - & - & - & 425.162 \\
Convection \& radiation loss & - & - & - & 193.285 \\
Water evaporation process & - & - & - & 6.741 \\
\hline Total of mass \& heat flow & 3.3375 & 869.085 & 3.3375 & 870.728 \\
\hline
\end{tabular}

TABLE 5. Plant materials and heat flows per kg of clinker produced.

\begin{tabular}{lcccc}
\hline \multirow{2}{*}{ Parameters } & \multicolumn{2}{c}{ Inlet } & \multicolumn{2}{c}{ Outlet } \\
& mass $(\mathrm{kg})$ & heat $(\mathrm{kcal})$ & mass $(\mathrm{kg})$ & heat(kcal) \\
\hline Clinker from kiln & 1.1500 & 428.488 & - & - \\
Cooling air & 1.3239 & 9.440 & - & - \\
Clinker product & - & - & 1.0000 & 37.289 \\
Return clinker dust to kiln & - & - & 0.1500 & 34.201 \\
Combustion air & - & - & 1.3239 & 328.863 \\
Convection \& radiation loss & - & - & - & 37.375 \\
\hline Total of mass \& heat flow & 2.4739 & 437.928 & 2.4739 & 437.728 \\
\hline
\end{tabular}

TABLE 6. Materials and heat flows of cooler per $\mathrm{kg}$ of clinker produced.

\begin{tabular}{lcccc}
\hline \multirow{2}{*}{ Parameters } & \multicolumn{2}{c}{ Inlet } & \multicolumn{2}{c}{ Outlet } \\
& mass $(\mathrm{kg})$ & heat $(\mathrm{kcal})$ & mass $(\mathrm{kg})$ & heat(kcal) \\
\hline Kiln feed from SP & 1.5636 & 346.300 & - & - \\
Coal to main burner & 0.1370 & 837.102 & - & - \\
Combustion air & 1.5189 & 330.393 & - & - \\
Return clinker dust from cooler & 0.1500 & 34.201 & - & - \\
Produced clinker & - & - & 1.1500 & 428.488 \\
Recirculating clinker dust to SP & - & - & 0.1700 & 50.630 \\
Flue gas to SP & - & - & 1.6381 & 537.000 \\
Kiln feed gas & - & - & 0.4114 & 134.900 \\
Net of calcination and clinkerization heat & - & - & - & 293.310 \\
Evaporating of coal moisture content & - & - & - & 3.846 \\
Convection \& radiation loss & - & - & - & 92.730 \\
\hline Total of mass \& heat flow & 3.3695 & 1547.996 & 3.3695 & 1540.904 \\
\hline
\end{tabular}

TABLE 7. Materials and heat flows of kiln per $\mathrm{kg}$ of clinker produced. 


\begin{tabular}{lcccc}
\hline \multirow{2}{*}{ Parameters } & \multicolumn{2}{c}{ Inlet } & \multicolumn{2}{c}{ Outlet } \\
& mass $(\mathrm{kg})$ & heat (kcal) & mass (kg) & heat(kcal) \\
\hline Kiln feed & 1.6155 & 20.442 & - & - \\
Recirculating clinker dust from kiln & 0.1700 & 50.630 & - & - \\
Flue gas from kiln & 1.7042 & 541.660 & - & - \\
Kiln feed gas from kiln & 0.4114 & 134.900 & - & - \\
Kiln feed to the kiln & - & - & 1.5636 & 346.300 \\
Combustion gas including excess air & - & - & 1.7042 & 154.620 \\
Kiln feed gas out & - & - & 0.5528 & 46.744 \\
Return dust flow & - & - & 0.0805 & 6.887 \\
Heat of calcination process & - & - & - & 131.800 \\
Evaporating of kiln feed water content & - & - & - & 2.894 \\
Convection \& radiation loss & - & - & - & 63.180 \\
\hline Total of mass \& heat flow & 3.9011 & 747.632 & 3.9011 & 752.425 \\
\hline
\end{tabular}

TABLE 8. Materials and heat flows of SP per $\mathrm{kg}$ of produced clinker.

kiln is returned back to the SP. By limiting the difference between the heat flows in and out of the kiln to $\leq 1 \%$, we can estimate the percentage of the kiln feed calcined in the SP and in the kiln. The calculation results of this heat conservation show that about $25 \%$ of the kiln feed is calcined in the SP while the remaining $75 \%$ are calcinated in the kiln. In addition, using Equations (20) and (21), we can evaluate that the heat released during the sintering process in the kiln is about $102.2 \mathrm{kcal} / \mathrm{kg}$ of clinker produced.

We can also analyse that the heat carried by the clinker to the cooler, and by the gas from the fuel combustion and calcination of the kiln feed out from the kiln to the SP is very large. In the cooler, the heat carried by the clinker is mostly recovered by the combustion air. In the SP, it is used for heating and the initial calcination process of the kiln feed. Moreover, it also appears that the heat loss to the environment (i.e. $92.73 \mathrm{kcal} / \mathrm{kg}$ of produced clinker) is also significant (i.e., greater than in the cooler). The value obtained is still in the range of the results of Radwan (2012) (50 - 140 kcal/kg of produced clinker) [5. In general, the specific heat loss will decrease with an increasing plant capacity. However, there are still opportunities to recover this heat loss for the purpose of increasing the plant efficiency.

\subsection{SP AND DETAIL EACH CYCLONE MASS AND HEAT CONSERVATIONS}

The focus of this research is to estimate the separation efficiency of cyclones in the SP with the smallest possible error of the difference between the flows of heat in and out. This certainly cannot be obtained by a direct measurement in the field. Hence, by using Equations 55 to 600 based on the data from gas and material temperature measurements at the inlet and outlet of each cyclone, the value of the separation efficiency approximation can be obtained. The results of calculating the mass and heat conservation in the SP are given in Table 8 From the results, we can conclude that the difference between the outgoing and incoming heat rates is insignificant $(0.64 \%)$. The percentage of calcined kiln feed in this SP is around $25 \%$ with around $8 \%$ in cyclone 3 and the remaining $17 \%$ in the lowest cyclone. Using Equations (52) to (54) and completion methods as described in equations (55) to (57), the mass and heat conservations in each cyclone can be obtained with the difference between the heat in and out being less than $1 \%$.

The mass and heat conservations in cyclones 1,2 and 3,4 are given in Tables 9 and 10 respectively. From the results of these calculations using Equations (58) to $(60)$, the estimated separation efficiency for cyclone 2 is $91.89 \%, 84.09 \%$ for cyclone 3 and $79.51 \%$ for the lowest cyclone.

The separation efficiency of the top cyclone has been evaluated by Eq. (66). The results of the mass and heat conservation calculation for each cyclone is highly useful for designing equipment, controlling the process and modifying equipment (e.g., estimating the rate of kiln feed flow to the calciner). Some studies that simulate the process in a calciner [22, 51] require data of the entering kiln feed flow, which generally come out of cyclone 3. Unfortunately, these studies did not explain the origin of this data, which of course cannot be measured directly at the plant while the plant is operating. With the results of the calculations as shown in Table 9 , the process simulation that occurs within the calciner is expected to be closer to the real conditions, because the data can be obtained in a more accurate way.

The results of calculating the separation efficiency of these cyclones depend on the measured temperature data. For example, in cyclone 3, the variation in temperature of material coming out of the cyclone 2 as well as the gas entering the cyclone 3 is $\pm 2{ }^{\circ} \mathrm{C}$, which practically does not affect the value of its separation efficiency. The lower value of the separation efficiency for the lower cyclone position is a common design referred to in cement plants. The top cyclone is designed with a high efficiency since the separation function is more dominant. 


\begin{tabular}{lcccc}
\hline \multirow{2}{*}{ Parameters } & \multicolumn{2}{c}{ Cyclone 1 } & \multicolumn{2}{c}{ Cyclone 2 } \\
& mass $(\mathrm{kg})$ & heat (kcal) & mass $(\mathrm{kg})$ & heat(kcal) \\
\hline Kiln feed & 1.6155 & 20.670 & - & - \\
Kiln feed from upper cyclone & - & - & 1.6966 & 138.396 \\
Kiln feed dust from lower cyclone & 0.1665 & 23.406 & 0.3572 & 64.028 \\
Flue gas from lower cyclone & 1.7042 & 247.467 & 1.7042 & 311.981 \\
Kiln feed gas from lower cyclone & 0.5479 & 76.000 & 0.5479 & 97.440 \\
Flue gas from kiln & - & - & - & - \\
Kiln feed gas from kiln & - & - & - & - \\
\hline Total of mass \& heat flow in & - & 367.543 & 4.3059 & 611.845 \\
\hline Separated kiln feed to the lower cyclone & 1.6966 & 138.396 & 1.8873 & 257.199 \\
Unseparated dust to upper cyclone/duct & 0.0805 & 6.887 & 0.1665 & 23.406 \\
Kiln feed gas & 0.5528 & 47.648 & 0.5479 & 76.000 \\
Flue gas including excess air & 1.7042 & 153.543 & 1.7042 & 247.467 \\
Kiln feed moisture evaporating process & - & 2.894 & - & - \\
Heat of calcination process & - & - & - & - \\
Convection \& radiation heat loss & - & 20.550 & - & 11.630 \\
\hline Total of mass \& heat flow out & 4.0341 & 367.543 & 4.3059 & 615.702 \\
\hline
\end{tabular}

TABLE 9. Materials and heat flows per kg of produced clinker of Cyclones 1 and 2.

\begin{tabular}{lcccc}
\hline \multirow{2}{*}{ Parameters } & \multicolumn{2}{c}{ Cyclone 3 } & \multicolumn{2}{c}{ Cyclone 4 } \\
& mass $(\mathrm{kg})$ & heat (kcal) & mass (kg) & heat(kcal) \\
\hline Kiln feed from upper cyclone & 1.8873 & 257.199 & 1.8875 & 330.592 \\
Kiln feed dust from lower cyclone & 0.4029 & 92.839 & 0.1700 & 50.630 \\
Flue gas from lower cyclone & 1.7042 & 397.520 & - & - \\
Kiln feed gas from lower cyclone & 0.5024 & 115.400 & - & - \\
Flue gas from kiln & - & - & 1.7042 & 541.526 \\
Kiln feed gas from kiln & - & - & 0.4114 & 134.900 \\
\hline Total of mass \& heat flow in & 4.4968 & 862.958 & 4.1731 & 1057.648 \\
\hline Separated kiln feed to the lower cyclone & 1.8875 & 330.592 & 1.5636 & 346.306 \\
Unseparated dust to upper cyclone/duct & 0.3572 & 64.028 & 0.4029 & 92.839 \\
Kiln feed gas & 0.5479 & 97.440 & 0.5024 & 115.400 \\
Flue gas including excess air & 1.7042 & 311.981 & 1.7042 & 397.520 \\
Kiln feed moisture evaporating process & - & - & - & - \\
Heat of calcination process & - & 43.950 & - & 87.890 \\
Convection \& radiation heat loss & - & 12.330 & - & 18.670 \\
\hline Total of mass \& heat flow out & 4.4968 & 860.321 & 4.1731 & 1058.625 \\
\hline
\end{tabular}

TABLE 10. Materials and heat flows per kg of produced clinker of Cyclones 3 and 4. 
In addition to controlling the process, a high efficiency of the top cyclone is also intended to reduce the amount of pollutant emissions released into the environment. Whereas for the 3 lower cyclones, their heat transfer function is more important. From Tables 8 and 9 it can be seen that the heat carried by the gas coming out of the top-cyclone is significantly high (more than $200 \mathrm{kcal} / \mathrm{kg}$ of clinker produced). This heat can be recovered for drying fine coal, lime stone and clay as reported by Alfi et.al [52].

\section{Conclusions}

Equations and a new approach to precisely calculate the mass and heat conservations in a single string cement plant are presented in this paper. Using the proposed new method, the detail mass and heat conservation in each main equipment (e.g., cooler, kiln, SP and cyclones) can be evaluated based on common data available in the control room and measuring the surface temperature of the main equipment. As a case study, operational data of Tonasa 2 cement plant were used for the detailed mass and heat conservation evaluation. The conclusions that can be drawn from the results of this study are as follows:

(1.) The advantage of this proposed method over the conventional method of calculating the mass and energy flow of a clinker plant is that it can estimate the mass and energy flow in each cyclone so that the separation efficiency of each cyclone, which is impossible to measure, can be evaluated. This cannot be done with conventional methods, which only evaluate the SP as a whole. The estimated separation efficiency value of each cyclone can be obtained with less than $1 \%$ error in heat conservation.

(2.) This proposed method can also be used to estimate several parameters that cannot be obtained by a direct measurement of a running plant (e.g. combustion air temperature at the exit from the cooler, and clinkerization heat).

(3.) The results obtained are expected to be used as additional data in controlling operations, designing new equipment and modifying the processes and dimensions of an existing equipment.

(4.) The proposed calculation method can be applied to all types of modern cement clinker plant configurations, either with or without a calciner including the double strings. It is also expected to contribute to design process improvement, operation simulation of a calciner and controlling the daily operation of a clinker plant.

\section{LIST OF SYMBOLS}

$A$ surface area $\left[\mathrm{m}^{2}\right]$

ash Mass percentage of ash in coal [\%]

En Heat flow rate $[\mathrm{kcal} / \mathrm{s}, \mathrm{kW}]$

$m$ Mass flow rate $[\mathrm{kg} / \mathrm{s}]$

$N H V$ Nett heating value $[\mathrm{kcal} / \mathrm{kg}, \mathrm{kJ} / \mathrm{s}]$

$\eta \quad$ Materials separation efficiency of the cyclone [\%]

LOI Loss of ignition [\%]

$\mathrm{H}_{2} \mathrm{O}$ Mass flow rate of vapor $[\mathrm{kg} / \mathrm{s}]$

$h_{x}\left(T_{x}\right)$ Enthalpy of substance $x$ at temperature $T_{x} \quad[\mathrm{kcal} / \mathrm{kg}]$

$h_{f g}$ Enthalpy of evaporation $[\mathrm{kcal} / \mathrm{kg}$ ]

$h_{k f} \quad$ Enthalpy of kiln feed [kcal $/ \mathrm{kg}$ ]

$\left(\mathrm{CaCO}_{3}\right)_{k f}$ Mass percentage of $\mathrm{CaCO}_{3}$ [\%]

$\left(\mathrm{MgCO}_{3}\right)_{k f}$ Mass percentage of $\mathrm{MgCO}_{3} \quad$ [\%]

$\left(\mathrm{SiO}_{2}\right)_{k f}$ Mass percentage of $\mathrm{SiO}_{2} \quad[\%]$

$\left(\mathrm{Al}_{2} \mathrm{O}_{3}\right)_{k f}$ Mass percentage of $\mathrm{Al}_{2} \mathrm{O}_{3} \quad$ [\%]

$\left(\mathrm{Fe}_{2} \mathrm{O}_{3}\right)_{k f}$ Mass percentage of $\mathrm{Fe}_{2} \mathrm{O}_{3}$ [\%]

$T$ Temperature $[\check{\mathrm{r}} \mathrm{C}]$

$Q_{\text {loss }}$ Radiation and convection heat loss $[\mathrm{kcal} / \mathrm{s}, \mathrm{kW}]$

$\%$ Calc_k $k$ Percentage of kiln feed calcined in the kiln [\%]

$\%$ Calc_SP Calcined kiln feed percentage in SP [\%]

$\Delta E_{\text {cyclone }}$ Error of energy conservation law (the difference of heat in-flow and heat out-flow of the cyclone)

$\Delta m_{\text {cyclone }}$ Error of mass conservation law (the difference of mass in and mass out of the cyclone)

\footnotetext{
Subscripts

amb ambient

ash ash in coal

c clinker cooler

calc calcination process
} 
C Cyclone Separator

$C 1$ Cyclone 1 (top)

$C 2$ Cyclone 2

C3 Cyclone 3

C4 Cyclone 4 (lowest)

cli clinker

clid_to_k Clinker dust return to kiln

coal coal

coal - comb coal combustion process

cool-air clinker cooling air

cool_air_k cooling air to kiln

evap evaporation process

form clinker formation process

gas - kf kiln feed gas

$h g$ hot gas

hgi hot gas exit from Cyclone $i$

$\mathrm{H} 2 \mathrm{O}-\mathrm{kf}$ kiln feed evaporated water

$k \quad$ Kiln

$k f \quad$ kiln feed

$k f i$ separated kiln feed from Cyclone $i$

$S P$ Suspension Preheater

$s e c \_a i r \_c$ Combustion air from cooler to kiln

$s e p-k f$ separated kiln feed

$s e p-k f c$ separated kiln feed to form clinker

sep $-k f-i$ separated kiln feed by cyclone $i(i=1 \mathrm{~A}$ and 1B, 2, 3 and 4$)$

surf surface area

tr - air transporting air

tot whole plant

unsep_kf_i unseparated kiln-feed by cyclone $i,(i=1 \mathrm{~A}$ and $1 \mathrm{~B}, 2,3$ and 4$)$

vapor water vapor

vapor $-k f$ vapor from kiln feed

\section{REFERENCES}

[1] R. Virendra, B. Sudheer Prem Kumar, J. Suresh Babu, D. Rajani Kant. Detailed energy audit and conservation in a cement plant. International Research Journal of Engineering and Technology 2(1):248 - 256, 2015.

[2] N. Anantharaman. Energy audit in cement industry (1500 tpd). International Journal of Science Technology $\mathcal{E}^{3}$ Engineering 3(10):12 - 18, 2017.

[3] S. Sattari, A. Avami. Assessment of energy-saving opportunities of cement industry in Iran. In Proceeding of the 3rd IASME/WSEAS International Conference on Energy, Environment, Ecosystems and Sustainable Development, pp. 585 - 593. Citeseer, Agios Nikolaos, Greece, 2007.

[4] P. Khongprom, U. Suwanmanee. Environmental benefits of the integrated alternative technologies of the Portland cement production: A case study in Thailand. Engineering Journal 21(7):15 - 27, 2017. DOr:10.4186/ej.2017.21.7.15

[5] A. M. Radwan. Different possible ways for saving energy in the cement production. Advances in Applied Science Research 3(2):1162 - 1174, 2012.

[6] T. T. Ayu, M. H. Hailu, F. Y. Hagos, S. M. Atnaw. Energy audit and waste heat recovery system design for a cement rotary kiln in Ethiopia: A case study. International Journal of Automotive and Mechanical Engineering 12:2983 - 3002, 2015. DOI:10.15282/ijame.12.2015.14.0249

[7] M. Parmar, D. Solanki, B. Vegada. Energy and Exergy analysis of cement rotary kiln. International Journal of Advanced Engineering and Research Development 3(4):284 - 293, 2016.

[8] A. I. Okoji, D. E. Babatunde, A. N. Anozie, J. A. Omoleye. Thermodynamic analysis of raw mill in cement industry using aspen plus simulator. In IOP Conference Series: Materials Science and Engineering, vol. 413, p. 012048. 2018. DOI:10.1088/1757-899X/413/1/012048.

[9] A. Kolip, A. F. Savas. Energy and exergy analyses of a parallel flow, four-stage cyclone precalciner type cement plant. International Journal of Physical Sciences 5(7):1147 - 1163, 2010. DOI:10.5897/IJPS.9000219.

[10] S. Jonnalagadda, S. Reddy. Heat transfer analysis of recuperative air preheater. International Journal of Engineering Research and Management 4(1):105 - 110, 2017. 
[11] L. K. Nørskov. Combustion of solid alternative fuels in the cement kiln burner. Ph.D. thesis, Technical University of Denmark, 2012.

[12] H. Mikulčić, E. von Berg, M. Vujanović, N. Duić. Numerical study of co-firing pulverized coal and biomass inside a cement calciner. Waste Management \& Research 32(7):661 - 669, 2014. DOI:10.1177/0734242X14538309

[13] C. Y. H. Chao, P. C. W. Kwong, J. H. Wang, et al. Co-firing coal with rice husk and bamboo and the impact on particulate matters and associated polycyclic aromatic hydrocarbon emissions. Bioresource Technology 99(1):83 93, 2008. DOI:10.1016/j.biortech.2006.11.051

[14] Verein Deutscher Zementwerke. Activity Report: Process Technology of Cement manufacture. Utilisation of used tyres in cement works. Tech. rep., Verein Deutscher Zementwerke, 2003 - 2005.

[15] S. Kourounis, S. Tsivilis, P. E. Tsakiridis, et al. Properties and hydration of blended cements with steelmaking slag. Cement and Concrete Research 37(6):815 - 822, 2007. DOI:10.1016/j.cemconres.2007.03.008

[16] M. Varma, P. Gadling. Additive to cement, A pozzolanic material-fly ash. International Journal of Engineering Research 3(5):558 - 564, 2016. DOI:10.17950/ijer/v5i3/010

[17] D. A. Y. Ghassan K. Al-Chaar, L. A. Kallemeyn. The Use of Natural Pozzolan in Concrete as an Additive or Substitute for Cement. ERDC/CERL TR-11-46. Tech. rep., Federal University of Technology, Minna, Niger.

[18] A. Allahverdi, S. Salem. Studies on main properties of ternary blended cement with limestone powder and microsilica. Iranian Journal of Chemical Engineering 4(1):3 - 13, 2007.

[19] D. Paa, P. Darmanto. Studi Numerik Pengaruh Laju Umpan Kiln terhadap Rugi Tekanan dan Efisiensi Pemisahan Top Siklon Suatu Pabrik Semen. In Proceeding Seminar Nasional Tahunan Teknik Mesin XIII (SNTTM XIII), pp. $625-630.2014$.

[20] P. S. Darmanto, I. M. Astina, A. Syahlan. Design and Implementation of Deduster for Improving Fine Coal Quality in a Cement Plant. In The International Conference on Fluid and Thermal Heat Conversion (FTEC). Tongyeong, South Korea, 2009.

[21] H. Mikulčić, E. Von Berg, M. Vujanović, N. Duić. Numerical study of co-firing pulverized coal and biomass inside a cement calciner. Waste management \& research 32(7):661 - 669, 2014. DOI:10.1177/0734242X14538309.

[22] A. C. Kahawalage, M. C. Melaaen, L.-A. Tokheim. Numerical modeling of the calcination process in a cement kiln system. In Linköping Electronic Conference Proceedings, vol. 138, pp. 83 - 89. Reykjavik, Iceland, 2017. DOI:10.3384/ecp1713883

[23] G. Borsuk, J. Wydrych, B. Dobrowolski. Modification of the inlet to the tertiary air duct in the cement kiln installation. Chemical and Process Engineering 37(4):517 - 527, 2016. DOI:10.1515/cpe-2016-0042

[24] Claus Bauer. Modernization and production increase with cement kilns. Humbolt report. Tech. rep., KHD Humboldt Wedag AG, 2000.

[25] X. D'Hubert. Latest burner profiles. Global Cement Magazine 03, 2017.

[26] N. Gopani, A. Bhargava. Design of high efficiency cyclone for tiny cement industry. International Journal of Environmental Science and Development 2(5):350 - 254, 2011. DOI:10.7763/IJESD.2011. V2.150

[27] H. Mikulčić, E. Von Berg, M. Vujanović, et al. Numerical analysis of cement calciner fuel efficiency and pollutant emissions. Clean Technologies and Environmental Policy 15(3):489 - 499, 2013. DOI:10.1007/s10098-013-0607-5.

[28] A. T. Gebremariam. CFD Modelling and Experimental Testing of Thermal Calcination of Kaolinite Rich Clay Particles - An Effort towards Green Concrete. Ph.D. thesis, Aalborg University, Denmark, 2015.

[29] Y. Sonavane, E. Specht. Numerical analysis of the heat transfer in the wall of rotary kiln using finite element method ANSYS. In Seventh International Conference on CFD in the Minerals and Process Industrie CSIRO, pp. 1 5. Melbourne, Australia, 2009.

[30] E. Copertaro, A. A. Estupinan Donoso, B. Peters. A discrete-continuous method for predicting thermochemical phenomena in a cement kiln and supporting indirect monitoring. Engineering Journal 22(6):165 - 183, 2018. DOI:10.4186/ej.2018.22.6.165.

[31] Z. Dulaimi, H. Hameed, A. Ali, M. Alfahham. Investigation the effect of calcinations degree and rotary kiln gases bypass opining in the preheating system for dry cement industries. International Journal of Latest Trends in Engineering and Technology 10(3):119 - 127, 2018. DOI:10.21172/1.103.21.

[32] F. L. Smidth. Preheater calciner systems. WwW.flsmidth-prod-cdn.azureedge.net/-/media/brochures/brochures-products/pyro/2000-2017/ preheater-calciner-systems .pdf?rev=3519484b-6b80-47ee-811a-b69f889f353f, 2011.

[33] A. Atmaca, R. Yumrutaş. Analysis of the parameters affecting energy consumption of a rotary kiln in cement industry. Applied Thermal Engineering 66(1-2):435 - 444, 2014. DOI:10.1016/j.applthermaleng.2014.02.038

[34] S. B. Nithyananth, H. Rahul. Thermal heat audit of kiln system in a cement plant. International Journal of Modern Engineering Research 5(12):73 - 79, 2015. 
[35] P. Prasanth, G. Sudhakar. Analysis of heat loss in kiln in cement industry - A review. In International Conference on Explorations and Innovations in Engineering 83 Technology (ICEIET -2016).

[36] D. Touil, H. Belabed, C. Frances, S. Belaadi. Heat exchange modeling of a grate clinker cooler and entropy production analysis. International Journal of Heat and Technology 23(1):61 - 68, 2005.

[37] L. Farag. Energy and exergy analyses of egyptian cement kiln plant with complete kiln gas diversion through by pass. International Journal of Advances in Applied Sciences 1(1):35 - 44, 2012. DOI:10.11591/ijaas.v1i1.757

[38] F. L. Smidth. Dry Process kiln. FL Smidth Inc, USA, 2004.

[39] W. H. Duda. Cement Data Book I: International Process in the Cement Industry. French \& European Pubs, 3rd edn., 1985.

[40] D. K. Fidaros, C. A. Baxevanou, C. D. Dritselis, N. S. Vlachos. Numerical modelling of flow and transport processes in a calciner for cement production. Powder Technology 171(2):81 - 95, 2007. DOI:10.1016/j.powtec.2006.09.011.

[41] F. L. Smidth. Plant Services Devision. Heat Conservations. International cement production seminar, Lecture 5.13A. Tech. rep., FL Smidth Inc, 1990.

[42] T. Chatterjee. Burnability and clinkerization of cement raw mixes. In Advances in Cement Technology, pp. 69 113. Pergamon Press, 1983. DOI:10.1016/B978-0-08-028670-9.50009-0

[43] P. A. Aisop, H. Chen, H. Tseng. The cement plant operations handbook. Tradeship Publications Ltd, Surrey, UK, 5th edn., 2007.

[44] Holcim Group Support Ltd. Cement Manufacturing Services. Reference Guide for Process Performance Engineers. Thermal Process and Materials Technology, Edition 3.0. Tech. rep., Holcim Group Support Ltd., 2006.

[45] A. Howard, R. Chris. Elementary Linear Algebra. John Wiley and Sons Inc., United States, 9th edn., 2005.

[46] I. Markovsky. Low rank approximation - Algorithms, implementation, applications. Springer-Verlag London, 2012. DOI:10.1007/978-1-4471-2227-2.

[47] J. Chen, M. Shi. Analysis on cyclone collection efficiencies at high temperatures. China Particuology 1(1):20 - 26, 2003. DOI:10.1016/S1672-2515(07)60095-5.

[48] A.-N. Huang, N. Maeda, D. Shibata, et al. Influence of a laminarizer at the inlet on the classification performance of a cyclone separator. Separation and Purification Technology 174:408 - 416, 2017. DOI:10.1016/j.seppur.2016.09.053

[49] A. Amalia, A. Syahlan, P. S. Darmanto. Heat auditing of Gresik and Tonasa plants. Internal Project Report of Indonesian Cement and Concrete Institute. Tech. rep., Indonesian Cement and Concrete Institute, 2006.

[50] A. Amalia, A. Syahlan, P. S. Darmanto. Design and implementation of hot gas system for raw coal drying in Tonasa 3 Plant. Internal Project Report of Indonesian Cement and Concrete Institute. Tech. rep., Indonesian Cement and Concrete Institute, 2006.

[51] H. Mikulčić, E. Von Berg, M. Vujanović, et al. CFD analysis of a cement calciner for a cleaner cement production. Chemical Engineering Transactions 29:1513 - 1518, 2012. DOI:10.3303/CET1229253.

[52] A. Amalia, A. Syahlan, P. S. Darmanto. Modification of hot gas utilization for drying lime stone and clay at Tonasa 2 and 3 plants. Final Project Report of Indonesian Cement and Concrete Institute. Tech. rep., Indonesian Cement and Concrete Institute, 2007. 